\title{
Interactive comment on "Headwater sediment dynamics in debris flow catchment: implication of debris supply using high resolution topographic surveys" by A. Loye et al.
}

\section{O. Sass (Referee) \\ oliver.sass@uni-graz.at}

Received and published: 15 February 2016

This is a very interesting paper on sediment transport and sediment budget in an alpine catchment. The investigation was thoroughly performed and yielded an impressive amount of data. The data were carefully evaluated including an uncertainty analysis and are presented in (mostly) very good figures. The paper definitively warrants publication in ESurf after minor to moderate revisions.

The overall concept of the paper is very good. However, there are some problems with the presentation. The three most important points are:

The paper is not exactly easy to read because of the many details which are not clearly 
laid out. I understand that this is a huge body of data; and as methods, errors etc should be treated in sufficient depth, there is not very much potental for cuts. However, this little potential should be used.

The F/M-approach for rockfalls is very good. Nevertheless, it is not strictly necessary in the context of the contemporary sediment budget. I would suggest to leave it out and discuss this in detail in a second paper. This includes the section in the Methodology, but also in the Discussion, e.g. P19 L18-21; P20 L1-10; and Fig. 16.

The English is generally good but there are some (mostly minor) problems which a native speaker could easily correct to improve readability. (One is the rather odd, persistently wrong use of the word "any").

The Abstract should summarize aims, study sites, methods, results and the most important conclusions. Currently, it starts with a weird sentence; some facts are missing (time period of investigation, basic information on the catchment); and the results are not well structured.

In the Study Area section, any information on climate is missing. Quite frequently throughout the paper the authors mention e.g. "response to heavy rainstorms that occur regularly" (P5 L5). What is a "heavy rainstorm" in the area? Information on mean annual precipitation, rainstorm intensities, MAAT is entirely missing. Further example P16 L9: "series of rainfall of low to moderate intensity" - it is never defined what low intensity is.

The Introduction is well-written with a good number of references - nothing to improve on.

There is too much repetition and re-consideration of the own data in the Discussion towards the end, the paper gets tiresome to read. Consider to shorten the Discussion, with a stronger focus on the comparison to other work and on the geomorphic implications. More literature would be good in some places (e.g. P20 L14/15, and the entire

ESurfD

Interactive comment
Full screen / Esc

Printer-friendly version

Discussion paper 
sections 6.2 and 6.3). If other work is cited for comparison, it is mostly from French collegues working in the area. Most of paragraph 6.5 is rather speculative and could be left out (e.g. first sentences, and L11 ff)

The Conclusion is the weakest section of the paper. Here, there would be the chance to summarize the multitude of details in a clear way, maybe using bullet points. However, the paragraph is as confusing as much of the Results and Discussion are. By the start of the Conclusions, the reader is desperately waiting for some clear, summarizing facts: Which are the key findings after such a lot of details? Furthermore, the Conclusions should summerize the already presented findings and NOT come up with new ideas (e.g. lines 5-7 are unclear and something new; wet snow avalanches (L16) have never been mentioned before, and so on). Quite a lot of the Conclusions (if not all) is in fact Discussion (e.g. P26 L1-4).

\section{Figures/Tables}

Table 1. TLS dates of acquisitions: In the text you speak of a "five-day survey" while here it seems to be one defined day for each survey. Do you mean "five surveys of one day each" in the text body? (If so, it seems like an impressive survey speed to achieve 50 scans from 9 viewpoints in a day..?)

Table 4. Sediment budget: It is not clear to me what the difference between "channel deposition input" and "sediment input" is; and what "total sediment" means

Figure 1: The inset is not ideal as you can't see any topography at all, and a legend of the geological units is missing.

Figure 2: I assume that the thick blue lines are the main torrents. However, the white lines are not explained in the legend.

Full screen / Esc

Figure 3: The Figure does not provide much important information and should be left out. I think that Fig. 1 and Fig. 4 are sufficient; maybe some of the names could be added in Fig. 1.

ESurfD

Interactive comment
Printer-friendly version

Discussion paper 
Fig. 4: Are the black symbols check dams?

Fig. 7,8,9: It would be better to use the same colour charts throughout the three consecutive figures. Fig. 9 should use the same legend as in Fig. 7 and 8 (black circle around the rockslope erosion dots)

Fig. 10: It makes not much sense to show the data for each period - the entire study time $(d)$ is sufficient.

Figure 12: Very good figure - after some trying to understand, all important parts of the budget become clear.

Fig. 13,14,15 are excellent figures.

Fig. 16: leave out

Minor comments

P5 L8: what does "any" mean in this context?

P5 L9: delete "a"

P5 L9: "old rock deposits flooring the hillslope side west (Fig. 3)" - This can't be seen in Fig. 3 (more in Fig. 4). I suggest to leave out Fig. 3.

P5 L11: resulting in

P5 L13: five (spell out numbers <13)

P5 L26: rockfall CAN reach

P6 L17/18: "The entire coverage of the upper catchment" - later it becomes clear that the coverage is 'only' $84 \%$ of the deforested area. Thus, reword here.

P7 L3: "procedure" instead of "manner"

P7 L5: Each of the multile scans...

\section{ESurfD}

Interactive comment
Full screen / Esc

Printer-friendly version

Discussion paper 
P8 L1: computes

P8 L4: what does "of similar sign" mean?

ESurfD

P9 L13: "cell differences lying below a given threshold" - which was this threshold?

P12 L19: "did not show any" instead of "showed any"

P13 L15: spatial extent

P13 L18: did not show any

P13 L22: signs

P13 L23: rilling areas

P14 L10: rock slope erosion

P14 L20: rockfalls

P15 L13: "almost without any" instead of " with almost any"

P16 L5: in the torrent

P16 L9: "no" instead of "any"

P16 L14: rainfalls

P16 L19: "no" instead of "any"

P16 L20: "No" instead of "Any"

P17 L1: Synthesis

Full screen / Esc

P17 L8: "of which" instead of "whereas"

P17 L14 "acts as recharging the torrent" - reword, what does this mean?

Printer-friendly version

P18 L15: delete "degradation"

Discussion paper

P18 L21: "the bedrock surface is often highly fractured, suggesting frost shattering."

Interactive

comment

C5 
- This is a case of wrong reasoning and self-fulfilling prophecy (which is frequently found in this context). The fact that the bedrock surface is highly fractured is, it itself, no ESurfD indication of frost action. It might be fractured for tectonic-lithological reasons, or by the impact of any other type of weathering (hydration, solution processes, wetting/drying...)

P20 L3: "No" instead of "Any"

P20 L27: "For the entire area" instead of "globally" (which would be earth-wide)

P21 L21: "sediment density" instead of "process density"?

P23 L7: exhaustion instead of starvation

P23 L8: "no" instead of "any"

Interactive comment on Earth Surf. Dynam. Discuss., doi:10.5194/esurf-2015-48, 2016. 